Carta ao Editor / Letter to Editor

\section{Contribuição do estudo molecular de hemoglobinas S-like para o conhecimento da diversidade genética da população brasileira}

The contribution of molecular studies of S-like
hemoglobins to knowledge of the genetic
diversity of the Brazilian population

Ana R. Chinelato-Fernandes ${ }^{1}$

Claudia R. Bonini-Domingos ${ }^{2}$

'Bióloga, Doutora pelo programa de Pós-graduação em Genética do Instituto de Biociências, Letras e Ciências Exatas - Ibilce Unesp.

${ }^{2}$ Profa Dra. responsável pelo Laboratório de Hemoglobinopatias e Genética das Doenças Hematológicas (LHGDH) - Ibilce Unesp.

\section{Senhor Editor:}

As variantes de hemoglobinas são originadas por diferentes mecanismos que resultam em mudanças nas propriedades físicas, químicas ou funcionais da molécula de hemoglobina. Mais de 900 variantes de hemoglobinas já foram descritas, ${ }^{1}$ sendo que mais de uma centena apresenta migração semelhante à $\mathrm{Hb} \mathrm{S}$ em pH alcalino; dentre essas, as hemoglobinas D-Los Angeles, $\mathrm{Hb}$ Korle-Bu, Hb G Philadelphia, $\mathrm{Hb}$ Lepore e $\mathrm{Hb}$ Hasharon estão entre as mais freqüentemente encontradas. A população brasileira formou-se a partir de três grupos étnicos: os indígenas, os caucasianos e os afrodescendentes. Entre os caucasianos destacam-se os italianos, espanhóis, alemães, além dos japoneses, ampliando e diversificando ainda mais a formação étnica da nossa população. Atualmente, a população brasileira caracteriza-se por apresentar grande heterogeneidade genética, que se reflete nos polimorfismos de hemoglobinas.

O objetivo deste trabalho foi identificar e caracterizar as variantes de hemoglobinas que apresentam migração eletroforética semelhante à $\mathrm{Hb} \mathrm{S}$ em $\mathrm{pH}$ alcalino, relacionando-as com as diferentes populações que contribuíram para a diversidade genética da população brasileira.

Durante o período de julho de 2000 a fevereiro de 2003 foram analisadas 220 amostras de sangue periférico de indivíduos com suspeita de serem por- tadores de hemoglobinas variantes, provenientes de oito estados do Brasil (Figura 1). Desse total, 98 amostras apresentaram uma fração hemoglobínica com padrão de migração semelhante à $\mathrm{Hb} \mathrm{S}$ em eletroforese alcalina em acetato de celulose.

Foram utilizadas amostras de sangue periférico colhido com EDTA, após consentimento informado. Para o correto diagnóstico e caracterização dessas hemoglobinopatias, foram realizadas metodologias clássicas e moleculares, que incluíram: $0,36 \% 0^{2}$

- Resistência globular osmótica em solução de $\mathrm{NaCl}$ a

- Análise da morfologia eritrocitária a fresco ${ }^{3}$

- Eletroforese alcalina - pH 8,6

- Eletroforese ácida - pH 6,2 ${ }^{5}$

- Eletroforese de cadeias globínicas em pH alcalino ${ }^{6}$

- Cromatografia líquida de alta pressão (HPLC)*

- Análise molecular por PCR-RFLP ${ }^{7}$

- PCR-ASO

- Seqüenciamento ${ }^{8}$

A associação dos resultados obtidos nos diferentes procedimentos citológicos, eletroforéticos e cromatográficos permitiu a indicação da suspeita de cada amostra e posterior definição da estratégia para confirmação molecular. A tabela 1 ilustra o número de mutantes encontrados e a estratégia utilizada para confirmação molecular.

O Brasil foi inicialmente colonizado por portugueses no século XVI, período em que teve início a miscigenação entre colonizadores e ameríndias nativas e, a partir da segunda metade do século 16, com escravas africanas. O fim do tráfico de escravos provocou o desembarque maciço de imigrantes europeus no País. Entre 1884 a 1945, recebemos cerca de quatro milhões de imigrantes europeus, em particular italianos, portugueses, espanhóis e alemães, além de mais de 100 mil russos e quase 200 mil japoneses. Outras nacionalidades, como poloneses, austríacos, gregos, armênios, holandeses, suíços, húngaros, libaneses, sírios, jordânios e palestinos somaram, nesse mesmo período, mais de 500 mil imigrantes. ${ }^{9}$ Atualmente, o Brasil é um país altamente miscigenado e apresenta intensa heterogeneidade entre suas diferentes regiões. Essa heterogeneidade reflete o padrão peculiar de colonização dessas regiões, uma vez que variou

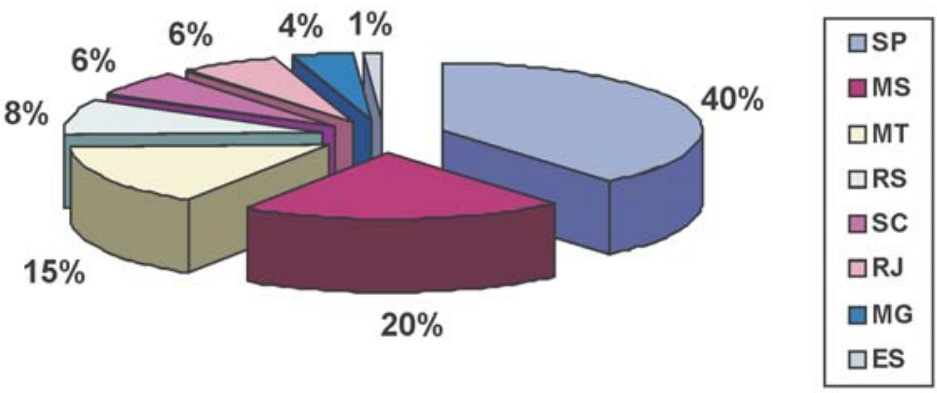

Figura 1: Valores percentuais de amostras analisadas, provenientes de diferentes estados brasileiros 
Tabela 1

Amostras analisadas através de metodologias clássicas e moleculares para a confirmação da hemoglobina variante

\begin{tabular}{ccc}
\hline Amostras & Mutante encontrado & $\begin{array}{c}\text { Estratégia utilizada para } \\
\text { confirmação }\end{array}$ \\
\hline 33 & HbA/D-Los Angeles & PCR-RFLP \\
2 & $\begin{array}{c}\text { Hb D-Los Angeles/ } \\
\text { talassemia beta }\end{array}$ & PCR-RFLP/PCR-ASO \\
1 & Hb D-Los Angeles/Hb S & PCR-RFLP/PCR-ASO \\
1 & Hb D-Los Angeles/Hb & PCR-RFLP/HPLC \\
10 & Lb A/Hb Korle-Bu & Seqüenciamento \\
1 & Hb Korle-Bu/Hb S & Seqüenciamento/PCR-ASO \\
11 & $\mathrm{Hb} \mathrm{A/Hb} \mathrm{Hasharon}$ & PCR-RFLP \\
39 & outras & \\
\hline
\end{tabular}

o número de indivíduos que compuseram o estoque genético de cada grupamento étnico parental.

Dentre as amostras analisadas molecularmente, notouse uma prevalência de $\mathrm{Hb}$ D-Los Angeles em heterozigose. Essa variante originou-se na Índia, mas devido à dispersão para outras regiões do mundo pelos movimentos migratórios, atualmente apresenta ampla distribuição mundial. Também foram encontrados casos de associações entre a Hb DLos Angeles e outras variantes e talassemias. Os indivíduos com a associação entre $\mathrm{Hb} \mathrm{D}$-Los Angeles e $\mathrm{Hb} \mathrm{S}$, conhecida como doença de $\mathrm{Hb} \mathrm{SD}$, podem desenvolver alterações graves, semelhantes clinicamente aos homozigotos para $\mathrm{Hb} \mathrm{S}$. A interação entre $\mathrm{Hb} \mathrm{D}$-Los Angeles e talassemia beta é bastante rara e foram relatados um caso no Canadá, três em Portugal, um na Inglaterra, um na Espanha, três no Kuwait, um na Índia, um na Rússia e dois na Arábia Saudita. ${ }^{10}$ Além disso, foi possível a descrição inédita na literatura da associação de $\mathrm{Hb}$ D-Los Angeles e Hb Lepore. A associação de $\mathrm{Hb}$ D-Los Angeles com outras variantes, como as descritas acima, não são inesperadas, se levarmos em consideração a grande miscigenação ocorrida no Brasil.

A $\mathrm{Hb}$ Korle-Bu é encontrada principalmente em famílias provenientes de Gana e Costa do Marfim, países africanos que contribuíram para a formação da população brasileira através do tráfico de escravos. Entretanto, os dados históricos sobre o tráfico indicam que os indivíduos dessa região foram levados preferencialmente para a região da Bahia. As amostras aqui descritas foram provenientes de indivíduos das regiões sudeste, sul e centro-oeste. Isto pode ser explicado pelo intenso fluxo migratório interno de indivíduos nordestinos para outros estados, em busca de novas oportunidades de emprego. A Bahia foi o segundo estado que mais contribuiu com trabalhadores para o estado de São Paulo. ${ }^{11}$

A Hb Lepore é uma variante originada pela fusão de cadeias delta e beta encontrada principalmente em italianos, mas pode ser encontrada também em ingleses, mexicanos, turcos, romenos, gregos e cubanos. A Hb Hasharon é uma variante de hemoglobina descrita principalmente em italia- nos e judeus Ashkenazi. A análise desses resultados confirmou os dados históricos que indicam a grande influência dos italianos na formação da população paulista, já que o estado de São Paulo transformou-se em um dos mais importantes pólos de atração de fluxos migratórios. Todos os indivíduos portadores de $\mathrm{Hb}$ Lepore e a grande maioria dos indivíduos portadores de $\mathrm{Hb}$ Hasharon amostrados residem no estado de São Paulo.

Apesar da maior parte das amostras analisadas ser proveniente dos estados da região sudeste, acredita-se que essa população apresente características encontradas por todo o país, uma vez que o padrão regional de miscigenação foi consideravelmente alterado pelas correntes de migração interna, fazendo da região sudeste o principal destino de grande contingente desses migrantes.

O correto diagnóstico laboratorial é de grande importância para os indivíduos portadores de hemoglobinopatias, especialmente no Brasil, tendo em vista os inúmeros casos de associação de alterações de hemoglobinas, além de variantes que apresentam co-migração, como os casos aqui descritos. A ocorrência de tais associações exige, portanto, que todos os recursos diagnósticos, em nível laboratorial, sejam utilizados em benefício do paciente e seus familiares. O esclarecimento diagnóstico destes casos é fundamental, tanto para a correta orientação genética quanto para se evitarem tratamentos inadequados ou desnecessários dos seus portadores.

\section{Abstract}

Over 900 hemoglobin variants have already been described, with more than 100 having electrophoretic migration similar to Hb S in alkaline pHs. In the analysis of 98 samples that presented with this migration pattern, Hb D-Los Angeles in heterozygosis was prevalent and associations with $\mathrm{Hb} \mathrm{S}$ and $\mathrm{Hb}$ Lepore were identified, a previously unpublished fact and with beta-thalassemia, which is also rare. In addition, carriers of $\mathrm{Hb}$ Korle-Bu and Hb Hasharon were found amongst other hemoglobinopathies. This heterogeneity reflects the special colonization conditions and the high racial admixture in Brazil. The correct laboratorial diagnosis is very important for hemoglobinopathy carriers because of the many associations of hemoglobin alterations and the variants with comigration. An accurate identification of hemoglobin variants is essential for genetic counseling and appropriate therapy.

Key words: Hemoglobin variants; S-like hemoglobins; Co-migration.

\section{Referências Bibliográficas}

1. Wajcman $\mathrm{H}$ et al. Abnormal hemoglobins: laboratory methods. Hemoglobin 2001;25(2):169-181.

2. Silvestroni E and Bianco I. Screening for microcytemia in Italy: analysis of data collected in the past 30 years. Am J Hum Genet 1975;27:198-212.

3. Bonini-Domingos CR. Prevenção das hemoglobinopatias no Brasil - Diversidade Genética e Metodologia Laboratorial. 1993. 144f. Tese (Doutorado em Ciências) - Instituto de Biociências, Letras e Ciências Exatas, Unesp, São José do Rio Preto- SP. 
4. Marengo-Rowe AJ. Rapid electrophoresis and quantification of hemoglobin on cellulose acetate. J Clin Path 1965;18:790-792.

5. Vella F. Acid agar gel electrophoresis of human hemoglobin. Am J Clin Path 1968;49(3):440-442.

6. Schneider RG. Differentiation of electrophoretically Similar hemoglobins - such as S, D ou G and P or $\mathrm{A}_{2}, \mathrm{C}, \mathrm{E}$ and $\mathrm{O}$ - by electrophoresis of the globin chains. Clin Chem 1974;20:1.1111.115 .

7. Saiki RK et al. Primer-directed enzymatic amplification of DNA with a thermostable DNA polymerase. Science 1988;230:487491.

8. Sanger F, Nicklen S, Coulson AR. DNA sequencing with chain terminating inhibitors. Proc Natl Acad Sci 1977;74(5):463-467.

9. Ministério das relações Exteriores. Reforma Agrária: compromisso de todos. Disponível em http://www.mre.gov.br Acesso em 29 maio 2003.

10. Ahmed M, Stuhrmann M, Bashawri L et al. The b-globin genotype E121Q/W15X (cd121GAA à CAA/cd15TGG à TGA) underlines $\mathrm{Hb} \mathrm{D/b}-(0)$ thalassemia marked by domination of haemoglobin $\mathrm{D}$. Ann Hematol 2001;80:629-633.

11. Governo so Estado de São Paulo. Site Oficial. Disponível em: http://www.saopaulo.sp.gov.br. Acesso em 29 maio 2003.

Avaliação: Editor e dois revisores externos.

Conflito de interesse: não declarado

Recebido: 21/06/2005

Aceito após modificações: 14/09/2005

Endereço para correspondência: Claudia Regina Bonini-Domingos Laboratório de Hemoglobinopatias e Genética das Doenças

Hematológicas LHGDH - Ibilce - Unesp

Rua Cristóvão Colombo, 2265 - Jardim Nazareth

15054-000 - São José do Rio Preto - SP

E-mail: claudiabonini@yahoo.com.br

\section{Deficiência de G-6-PD nos recém-nascidos de Uberaba, MG G-6-PD deficiency in neonates in Uberaba, MG}

\author{
Lizia M. F. R. Campos ${ }^{1}$ \\ Francisca L. Dias ${ }^{2}$ \\ Marcel Mendes ${ }^{3}$
}

'Pós-graduanda, mestrado em Patologia Clinica, UFTM. ${ }^{2}$ Professora, Disciplina de Genética, UFTM.

${ }^{3}$ Professor, Disciplina de Hematologia, Faculdade de Biomedicina, Uniube.

\section{Sr. Editor:}

A glicose-6-fosfato desidrogenase (G-6-PD) é uma enzima presente em todas as células, que catalisa o primeiro passo metabólico da hexose monofosfato, na via de shunt ou Desvio das Pentoses, produzindo NADPH; sua deficiência provoca alterações principalmente nos eritrócitos. ${ }^{1,2,3}$

De acordo com estudos moleculares, as variantes de G6-PD mais freqüentemente caracterizadas no Brasil são a africana e a mediterrânea. ${ }^{4,5}$ A síntese de G-6-PD é regulada por um gene situado no cromossomo $\mathrm{X}$, sendo sua deficiência, portanto, mais freqüente no sexo masculino. ${ }^{6,7}$

A deficiência de G-6-PD pode estar associada à hiperbilirrubinemia dos recém-nascidos, especialmente nos casos mais graves, que atingem os grupos asiáticos e mediterrâneos. ${ }^{8} \mathrm{~A}$ icterícia neonatal que ocorre nos recém-nascidos com esta deficiência parece ser uma acentuação da icterícia fisiológica. Esta icterícia neonatal aparece no $2^{\circ}$ e o $5^{\circ}$ dia de vida, aumenta de intensidade e pode provocar, nos casos mais graves, alterações neurológicas. . $^{1,2,3}$

A deficiência de G-6-PD pode também provocar crises hemolíticas quando os portadores são expostos a drogas de poder oxidativo. ${ }^{3}$

Apesar de todas as desvantagens que a deficiência em G-6-PD causa, estudos mostram que houve evolução da espécie humana, conferindo proteção contra a malária, na África, há milhares de anos, motivo pelo quais deficientes em G-6-PD não contraem malária, devido a uma mutação genética. ${ }^{7,9,10}$

A presente comunicação verifica a incidência da deficiência em G-6-PD, em amostra de recém-nascidos da cidade de Uberaba-MG, com análise através de método cinético enzimático, semi-automatizado, para a determinação quantitativa da atividade G-6-PD.

Os testes foram realizados no Laboratório de Análises Clínicas da Faculdade de Biomedicina, da Universidade de Uberaba, sendo as amostras de sangue coletadas de cordão 